\title{
TRADISI MAPPASSILI SEBAGAI SALAH SATU PENENTU KEPUASAN KONSUMEN BUGIS-MAKASSAR PASCA PEMBELIAN PRODUK DI KOTA MAKASSAR
}

\author{
Kasnaeny Karim¹, Muhammad Jibril Tajibu² \\ 1Program Studi Manajemen Keuangan dan Perbankan STIM Nitro, Makassar \\ ${ }^{2}$ Fakultas Ekonomi dan Bisnis, Universitas Hasanuddin, Makassar
}

\begin{abstract}
Abstrak $\quad$ Ketika melakukan pembelian barang konsumtif (kendaraan, rumah, dan barang mewah lainnya), masyarakat Bugis-Makassar akan menyelenggarakan upacara khusus pasca pembelian dan sebelum menggunakan produk yang dinamakan dengan Mappassili. Penelitian ini mengkaji perilaku konsumen pasca pembelian produk berdasarkan budaya lokal. Tujuan penelitian adalah untuk mengkonstruksi dan menelusuri alasan masih dilakukannya tradisi mappasili dan bagaimana tingkat kepuasan konsumen pasca dilakukannya tradisi tersebut pada suku Bugis-Makassar di Kota Makassar. Penelitian ini menggunakan metode penelitian kualitatif. Pengumpulan data dilakukan melalui wawancara mendalam pada 20 orang informan penelitian yang diperoleh melalui teknik snowball sampling. Hasil penelitian menunjukkan bahwa meskipun telah hidup secara modern, masyarakat suku Bugis-Makassar masih tetap melaksanakan tradisi mappasili setelah melakukan pembelian produk agar terhindar dari bahaya maupun atas desakan dari orang tua/keluarga. Kegiatan tersebut dilakukan tidak hanya untuk menghasilkan kepuasan, namun juga memberi perasaan aman dan nyaman pada masyarakat yang melakukan tradisi tersebut setelah pembelian dan ketika mengkonsumsi produk.
\end{abstract}

Kata Kunci : Suku Bugis-Makassar, Mappassili, perilaku pasca pembelian

\begin{tabular}{l|l} 
Abstract & $\begin{array}{l}\text { Related to the purchase and consumption of consumptive products (e.g., vehicles, houses, } \\
\text { and other luxury goods), Bugis-Makassar society will perform a local tradition called } \\
\text { Mappassili, which is a special ceremony performed after purchasing and before consuming } \\
\text { the product. This study examines the post-purchase consumer behavior related to local } \\
\text { culture. The objective of this study is to analyze the reasons behind the existence of } \\
\text { Mappassili tradition and to examine customer satisfaction after implementing this tradition } \\
\text { in Bugis-Makassar tribe in Makassar City. This study used a qualitative research method. } \\
\text { Data were collected through in-depth interviews with the sample consisted of } 20 \text { research } \\
\text { informants obtained by applying the snowball sampling technique. The results showed that } \\
\text { even though Bugis-Makassar tribe has lived in a modern way of life, they still implement the } \\
\text { Mappassili tradition after purchasing the product in order to avoid danger in life or due to } \\
\text { the pressure from the parents or families. The Mappassili tradition was not only performed } \\
\text { to achieve satisfaction, but also to obtain the feeling of security and comfort in purchasing } \\
\text { and consuming the product. }\end{array}$
\end{tabular}

Keywords : $\quad$ Bugis-Makassar tribe, Mappassili, post-purchase behavior 


\section{Pendahuluan}

Dalam membuat keputusan, konsumen akan selalu berinteraksi dengan lingkungannya. Lingkungan terdekat dengan konsumen adalah budaya yang telah mengakar dalam diri sejak lahir. Hal ini sesuai dengan pendapat Kotler dan Keller (2012) bahwa perilaku konsumen dalam pembelian produk dipengaruhi oleh faktor budaya. Salah satu bagian dari budaya adalah tradisi yang merupakan keyakinan mengenai nilai yang benar atau salah, yang melandasi seseorang dalam berperilaku (Noble et al., 1999). Dalam menganalisis perilaku konsumen, pemasar tidak hanya melihat dari penjualan sehari-hari tetapi juga harus terus melakukan riset terhadap konsumennya. Pengamatan terhadap konsumen tidak hanya dilakukan sebelum pembelian, yaitu faktor-faktor (internal dan eksternal) apa saja yang mempengaruhi konsumen ketika membeli produk, tapi juga memperhatikan bagaimana perilaku konsumen setelah pembelian (Pujangkoro, 2003).

Perilaku pasca pembelian merupakan reaksi yang terjadi pada konsumen setelah dilakukannya pembelian produk. Selanjutnya konsumen akan melalukan aktivitas terhadap produk tersebut, yang akan menghasilkan perasaan puas atau tidak puas setelah memilikinya. Demikian halnya pada masyarakat suku Bugis-Makassar yang mana terdapat aktivitas yang dilakukan setelah pembelian produk yang dikaitkan dengan budaya mereka. Masyarakat di Sulawesi Selatan yang terdiri dari suku Bugis, Makassar, dan Tator masih sangat dipengaruhi oleh budaya dalam perilaku pembelian produk, meskipun pada beberapa hal telah mengalami pergeseran dengan banyaknya pusat-pusat perbelanjaan dengan konsep 'barat' (Karim 2016).

Masyarakat Bugis Makassar dalam hal perilaku setelah pembelian masih mempertahankan tradisi mereka, yakni kepercayaan akan adanya keselamatan jika menggunakan produk tersebut dengan terlebih dahulu melakukan semacam upacara adat. Salah satu tradisi yang masih dilakukan oleh masyarakat di Sulawesi Selatan khususnya suku Bugis-Makassar adalah Mappassili.

Mappassili sebenarnya merupakan tradisi yang dibuat sebelum melakukan pernikahan, atau bagian dari tradisi pernikahan. Awalnya dikenal dengan "cemme passili" (Luchiyw 2014), yang mana calon pengantin akan dimandikan sebagai simbol permbersihan diri agar selamat dalam kehidupan dari hal-hal yang negatif (mengandung kesialan). Namun, dalam perkembangannya ritual ini juga dilakukan terhadap benda selain manusia, misalnya setelah melakukan pembelian produk yang spesial. Dilihat dari fenomena di lapangan, misalnya setelah melakukan pembelian produk, khususnya produk konsumtif yang tergolong barang mewah (kendaraan, rumah, atau barang lainnya), maka masyarakat suku Bugis-Makassar akan melakukan ritual tersebut, dengan menyiapkan berbagai bahan yang diperlukan, untuk selanjutnya disiramkan (memandikan) pada produk tersebut. Dengan demikian, masyarakat tidak akan menggunakan produk tersebut sebelum dilakukannya ritual Mappassili, sehingga diduga bahwa terdapat perilaku pasca pembelian pada konsumen, yang tidak langsung mengarah kepada keputusan "puas atau tidak puas" sebagaimana kajian teori perilaku konsumen. Dugaan itulah yang akan ditelusuri melalui penelitian, disebabkan belum adanya informasi mengenai kegiatan tradisi Mappassili terkait dengan perilaku pasca pembelian konsumen. Sementara fenomenanya adalah bahwa kegiatan ini dilakukan setelah pembelian (sebelum menggunakan produk tersebut) dan pada akhirnya akan menentukan pula tingkat kepuasan atau ketidakpuasan konsumen.

Pada kajian-kajian perilaku konsumen dikatakan bahwa konsumen akan melakukan pembelian didorong oleh adanya motivasi, dimana salah satu motivasi tersebut adalah budaya. Setelah mempertimbangkan produk yang dibeli dan kesesuaiannya dengan budaya, maka konsumen akan memutuskan untuk membeli. Setelah melakukan pembelian, maka konsumen akan mengevaluasi apakah produk tersebut sesuai atau tidak, jika sesuai maka 
mereka akan puas, dan jika tidak sesuai maka mereka akan membuangnya (Kotler dan Keller, 2012). Kajian mengenai kepuasan konsumen telah banyak dibahas, antara lain oleh Mosahab (2010), bahwa kepuasan konsumen dipengaruhi oleh reliability, responsiveness, assurance, empathy, dan tangibles, sementara itu kepuasan konsumen merupakan variabel antara menuju ke loyalitas konsumen. Demikian pula yang dinyatakan oleh Heine and Lehman di tahun 1977: "Cultural beliefs and values intervene in the economic decisions of consumers. Cultural values imply a widely held belief that has been internalized by individuals, as well as a general guide for some set of activities and behavior rules for them" (Kamaruddin dan Kamaruddin, 2009).

Setelah melakukan pembelian, maka konsumen akan melakukan beberapa tindakan terkait dengan kepuasan/ketidakpuasan pasca pembelian. Jika produk yang dibeli memenuhi harapan, maka mereka akan puas, dan jika tidak maka konsumen akan merasakan ketidakpuasan. Beragam kegiatan dilakukan oleh konsumen sebagai bentuk kepuasan atau ketidakpuasan. Dimana tindakan pasca pembelian tersebut beragam sesuai dengan budaya setempat. Hal ini sesuai dengan kajian Swimberghe et al. (2006) bahwa perilaku keputusan pembelian konsumen dipengaruhi antara lain oleh tingkat kereligiusan dan kepercayaan terhadap produk. Lin (2008) dalam penelitiannya terhadap warga Taiwan menemukan bahwa salah satu faktor yang dapat membuat konsumen puas setelah pembelian terkait dengan norma-norma positif masyarakat. Kondisi ini pun tampak pada masyarakat suku Bugis-Makassar dalam kegiatan pembelian mereka. Konsumen BugisMakassar akan selalu mengaitkan aktivitasnya dengan tradisi budaya, utamanya kepercayaan kepada Sang Pencipta, namun belum ada kajian terkait hubungan tradisi Mappassili dengan tingkat kepuasan pasca pembelian produk.

Berdasarkan beberapa pengamatan awal, dapat dikatakan bahwa perilaku pasca pembelian barang konsumtif berupa tradisi memanjatkan rasa syukur dan keselamatan kepada Allah SWT, namun belum ada kajian yang menguatkannya. Hal ini menjadi menarik untuk diketahui secara lebih mendalam mengenai apakah dengan dilakukannya tradisi Mappassili maka perilaku pasca pembelian pada masyarakat Bugis Makassar akan mengarah ke kepuasan konsumen pasca pembelian. Kajian-kajian yang ada terkait budaya, utamanya tradisi, lebih banyak menjelaskan keterkaitannya dengan tuntunan hidup dalam masyarakat. Misalnya oleh Luchiyw (2014) yang menyatakan bahwa tradisi Mappassili dilakukan pada wanita yang telah memasuki usia kehamilan 7 bulan, atau pada saat penempatan rumah baru, yang mana maknanya adalah untuk menolak bala atau menghindari dari malapetaka/bencana, menjauhkan dari roh-roh jahat sehingga segala kesialan hilang dan lenyap. Sementara itu belum ada kajian yang mengaitkan tradisi tersebut dengan perilaku konsumen pasca pembelian. Oleh karena itu, terdapat celah yang dapat dilakukan untuk penelitian lanjutan yang dikembangkan dari kajian yang telah ada. Selain itu adanya fenomena bahwa dalam perkembangan kehidupan dari masyarakat, dimana tradisi mappasili saat ini juga dilakukan terhadap produk-produk konsumtif, sehingga penelitan ini berupaya untuk mengisi celah (gap) penelitianpenelitian empiris sebelumnya, dimana belum terdapat kajian mengenai tingkat kepuasan/ketidakpuasan pembelian produk oleh konsumen dikaitkan dengan tradisi setempat, khususnya suku Bugis-Makassar di Kota Makassar.

Berdasarkan argumentasi sebelumnya, maka hal-hal yang ingin digali dari penelitian ini adalah: (a) alasan konsumen masih melakukan tradisi Mappassili meskipun konsumen tersebut telah hidup di zaman modern, (b) seberapa tinggi kepuasan yang dirasakan oleh konsumen Bugis-Makassar pasca pembelian produk setelah dilakukannya tradisi Mappassili. Hasil penelitian ini diharapkan dapat memberikan perspektif baru terhadap penggunaan dan kelengkapan teori perilaku pasca pembelian, untuk kajian selain tradisi kehidupan bermasyarakat. Selain itu, sebagai rujukan bagi penulis atau peneliti bidang sosiologi dan manajemen pemasaran, khususnya perilaku konsumen, dalam melakukan penelitian bersama di masa akan datang, serta melengkapi dan memperkaya khasanah ilmu pengetahuan di bidang 
manajemen pemasaran pada kajian perilaku pasca pembelian konsumen khususnya pada pada masyarakat suku Bugis Makassar.

\section{Metodologi}

\section{Pendekatan Penelitian}

Berdasarkan tujuan penelitian yang ingin dicapai, maka penelitian ini dirancang dengan menggunakan metode penelitian kualitatif untuk meneliti pada objek yang alamiah, dimana hasil penelitian kualitatif lebih menekankan pada makna daripada generalisasi. Penelitian kualitatif ini menggunakan data deskriptif berupa katakata tertulis atau jawaban-jawaban dari orang-orang dan perilaku yang diamati (Sugiyono, 2013).

\section{Subjek/Informan Penelitian}

Subyek penelitian atau informan ditentukan dengan teknik snowball dan purposive sampling. Informan ditentukan dengan kriteria: (1) merupakan suku Bugis-Makassar, (2) pernah melakukan tradisi Mappassili dalam pembelian produk konsumtif, dan (3) tidak dibedakan antara konsumen pria atau wanita. Keseluruhan informan berjumlah 20 orang, terdiri dari 10 orang suku Bugis dan 10 orang suku Makassar. Jumlah ini sesuai dengan kriteria dari Cresswell (2014) yang menyatakan bahwa jumlah informan sebanyak 10 orang sudah mencukupi dan kriteria jumlah sampel minimum menurut Giorgy (1991) yang menyatakan bahwa jumlah informan sebanyak 5 orang sudah cukup, namun jika jawaban atau informasi yang diinginkan belum tercapai (belum jenuh) maka dapat ditambahkan jumlahnya.

\section{Pengumpulan Data}

Pengumpulan data dilakukan melalui wawancara mendalam (in-depth interview) dan tidak terstruktur. Data yang terkumpul berupa: (1) data kata-kata (verbal) dan perilaku (non verbal) dari subjek penelitian. (2) data foto yang dikumpulkan untuk membantu memberikan penggambaran mengenai situasi perilaku konsumen, dan (3) data dokumentasi, dimana data ini merupakan data tambahan yang dapat diperoleh melalui dokumen-dokumen yang ada kaitannya dengan permasalahan penelitian.

\section{Teknik Analisis Data}

Analisis data dilakukan dengan menggunakan teknik analisis data deskriptif naratif. Menurut Milles et al (2014), deskriptif naratif merupakan kegiatan menganalisis data dengan cara: reduksi data, penyajian data, dan penarikan kesimpulan. Dalam proses analisis data tersebut peneliti menggunakan software pengolahan data kualitatif yang bernama NVivo,Ver.10 (Trial).

\section{Uji Validitas dan Realibilitas}

Pengujian keabsahan data dalam penelitian kualitatif dinamakan dengan uji kredibilitas, dependabilitas, dan konfirmabilitas. Kredibilitas dalam penelitian ini menggunakan teknik trianggulasi dan peer review (Creswell, 2014). Dependabilitas (reliabilitas) dilakukan melalui ketaatasasan pengukuran dan ukuran yang digunakan yang didasarkan pada asumsi replikabilitas atau keterulangan. Untuk itu dilakukan dengan mengkonfirmasi hasil wawancara, instrumen, makna-makna yang dirumuskan, dan catatan peneliti kepada orang-orang yang ahli di bidang penelitian kualitatif untuk dimintai tanggapannya. Sedangkan untuk konfirmabilitas, dilakukan bersama-sama dengan audit dependabilitas (Moleong, 2010).

\section{Instrumen Penelitian}

Instrumen penelitian dalam penelitian kualitatif adalah peneliti sendiri, sehingga peneliti harus mampu melakukan pendekatan kepada informan dalam mendapatkan keterangan-keterangan yang diperlukan. Adapun inti dari pertanyaan yang diajukan adalah:

1. Menanyakan alasan konsumen melaksanakan tradisi Mappassili setelah dilakukannya pembelian.

2. Menanyakan mengenai tingkat kepuasan dan ketidakpuasan konsumen setelah dilakukannya tradisi tersebut.

3. Selanjutnya pertanyaan akan dikembangkan sesuai dengan fenomena di lapangan. 


\section{Hasil dan Pembahasan}

\section{Karakteristik Informan}

Tabel 1 menunjukkan bahwa informan terpilih yang sesuai dengan karakteristik penelitian, yakni pernah melakukan pembelian produk konsumtif, seperti kendaraan dan rumah, serta melakukan tradisi Mappassili terdiri dari 12 orang laki-laki dan 8 orang perempuan.

\section{Tabel 1. Karakteristik Jenis Kelamin}

\begin{tabular}{ccc}
\hline No & Jenis Kelamin & Jumlah (orang) \\
\hline 1. & Laki-laki & 12 \\
2. & Perempuan & 8 \\
\hline
\end{tabular}

Sumber: Hasil Analisis Data

Paparan/Penyajian Data

Setelah dilakukan uji validitas dan reliabilitas, maka proses selanjutnya adalah memaparkan temuan penelitian. Hasil penelitian menunjukkan alasan konsumen masih melakukan tradisi Mappassili. Deskripsi tekstural terkait dengan perilaku, pemikiran, dan perasaan yang berkaitan dengan pengalaman informan disajikan di Tabel 2 . Tabel ini menunjukkan alasan informan melakukan tradisi Mappassili setelah pembelian produk yang pada dasarnya disebabkan oleh beberapa motif yang dikaitkan dengan adanya tujuan dari masingmasing informan tersebut.

Tabel 2. Hasil Reduksi Data

\begin{tabular}{clc}
\hline No. & \multicolumn{1}{c}{ Reduksi Data } & Tabulasi \\
\hline 1 & $\begin{array}{l}\text { Menginginkan keselamatan } \\
\text { saat menggunakan }\end{array}$ & 20 \\
2 & $\begin{array}{l}\text { Merasa nyaman jika } \\
\text { menggunakan produk setelah } \\
\text { melakukan Mappassili }\end{array}$ & 18 \\
3 & $\begin{array}{l}\text { Melaksanakan } \\
\text { amanat/desakan orang tua } \\
\text { dan keluarga }\end{array}$ \\
4 & $\begin{array}{l}\text { Sebagai ucapan syukur pada } \\
\text { tuhan YME }\end{array}$ & 16 \\
5 & Kebiasaan sejak dahulu & 9 \\
\hline
\end{tabular}

Sumber: Hasil Analisis Data

Berdasarkan Tabel 2 tersebut, maka dapat dijelaskan sebagai berikut:

1. Seluruh informan (20 informan) melakukan tradisi Mappassili setelah pembelian produk (rumah dan kendaraan) dengan harapan untuk mendapatkan keselamatan saat menggunakan produk tersebut.

2. 18 informan menyatakan melakukan tradisi tersebut karena ada perasaan nyaman menggunakan produk apabila telah dilakukan tradisi tolak bala tersebut serta disebabkan karena adanya pesan dari orang tua untuk tetap melakukan tradisi tersebut.

3. 18 informan juga menyatakan bahwa tradisi Mappassili dilakukan karena desakan orang tua/keluarga meskipun sebenarnya mereka tidak ingin melakukannya.

4. 11 informan menyatakan melakukan tradisi ini karena sebagai tanda syukur kepada Tuhan Yang Maha Kuasa, serta

5. 9 informan menyatakan sudah terbiasa melakukan hal tersebut setiap pembelian produk, sehingga merasa bahwa melakukan tradisi Mappassili adalah sebuah keharusan.

Jawaban atas pertanyaan penelitian mengenai tingkat kepuasan konsumen setelah melakukan tradisi Mappassili pasca pembelian produk dapat dilihat pada Tabel 3 berikut:

\section{Tabel 3. Tingkat Kepuasan}

\begin{tabular}{|c|c|c|}
\hline No. & Reduksi Data & Tabulasi \\
\hline 1 & $\begin{array}{l}\text { Sangat puas } r \text { saat } \\
\text { menggunakan produk yang } \\
\text { telah melalui tradisi } \\
\text { Mappassili }\end{array}$ & 9 \\
\hline 2 & Puas & 6 \\
\hline 3 & Biasa Saja & 5 \\
\hline 4 & Tidak Puas & 0 \\
\hline
\end{tabular}

Sumber: Hasil Analisis Data

Tabel 3 menunjukkan bahwa mayoritas konsumen sangat puas menggunakan produk yang terlebih dahulu diberi perlakuan melalui ritual upacara Mappassili. Namun, terdapat 5 konsumen yang menyatakan bahwa mereka tidak merasakan hal-hal khusus dengan pelaksanaan tradisi Mappassili pasca pembelian produk.

Berdasarkan hasil pengolahan data, maka terdapat beberapa temuan mengenai keterkaitan budaya dengan perilaku kepuasan pasca pembelian sebagai berikut: 
Alasan Melakukan Tradisi Mappassili Pasca Pembelian Produk

Hasil analisis menunjukkan bahwa masyarakat suku Bugis-Makassar masih melaksanakan upacara tolak bala atau Mappassili usai melakukan pembelian produk konsumtif. Kuatnya masyarakat BugisMakassar dalam memegang tradisi leluhur membuat mereka tetap melakukan ritual yang diajarkan oleh orang tua secara turun menurun. Adapun alasan yang melatarbelakangi perilaku tersebut adalah sebagai berikut:

1. Menginginkan keselamatan saat penggunaan produk.

Masyarakat suku Bugis-Makassar yang berdomisili di Kota Makassar masih memegang tradisi leluhur yang diajarkan oleh leluhur secara turun temurun. Meskipun agama Islam sudah mengajarkan mengenai ajaran-ajaran terkait keselamatan dunia akhirat, namun masyarakat tetap melakukan ritual upacara berupa tolak bala seusai melakukan pembelian produk. Hal ini dinyatakan oleh seorang informan bahwa: "Orang tua mengajarkan ritual untuk lakukan upacara tolak bala sebelum menggunakan produk, karena ada kekhawatiran bahwa kalau tidak melakukan maka akan ada saja masalah yang bisa membawa celaka atau kerugiankerugian"

Terkait dengan ajaran agama, seorang informan menyatakan:

"Mappassili tidak bertentangan dengan ajaran agama karena kita berdoanya kepada Tuhan sambil melakukan kegiatan itu dan meminta agar diberi keselamatan setiap saat."

Maksud dari pernyataan informan tersebut adalah meskipun ritual Mappassili merupakan adat leluhur yang sudah ada sejak sebelum masuknya agama Islam di Sulawesi Selatan, namun ritual tersebut intinya adalah permohonan kepada Yang Maha Kuasa agar terhindar dari bencana saat menggunakan produk.
2. Merasa nyaman menggunakan produk yang sudah melalui ritual Mappassili.

Bagi masyarakat Kota Makassar yang bersuku Bugis Makassar, mereka beranggapan bahwa melakukan ritual Mappassili adalah hal yang penting. Mereka menyatakan bahwa ada perasaan was-was jika ritual tersebut tidak dilakukan. Kondisi ini menyebabkan ketidaknyamanan karena terus dihantui perasaan akan tertimpa musibah jika tidak melakukan ritual tersebut seperti yang dikemukakan oleh salah seorang informan berikut:

"Takut rasanya kalau tidak lakukan..selalu ada perasaan nanti celaka kalau tidak di passili".

Perasaan tidak nyaman ini juga dapat disebabkan oleh karena keluarga akan selalu mendesak apabila ritual tersebut tidak dilakukan. Sehingga dapat disimpulkan bahwa sebenarnya terdapat juga masyarakat yang tidak ingin lagi melakukan ritual Mappassili, namun karena desakan keluarga menyebabkan adanya ketidaknyamanan dan memunculkan sikap ragu-ragu antara berpegang kepada keyakinan sendiri atau ikut saran orang tua.

3. Melaksanakan amanat/desakan orang tua dan keluarga

Sejak kecil orang tua mengajarkan adat istiadat dalam kehidupan sehari-hari, baik adat istiadat terkait kehidupan dalam keluarga, hingga bagaimana berhubungan dengan orang lain. Terkait dengan kepercayaan terhadap Tuhan, bagi umat Islam, orang tua selain mengajarkan rukun Islam dan rukun iman, juga mengajarkan ritual-ritual dalam melakukan permohonan kepada Tuhan Yang Maha Kuasa. Hal ini juga terkait dengan pernyataan nomor 2 bahwa kenyamanan menggunakan produk juga disebabkan oleh anjuran orang tua. Seorang informan menyatakan bahwa:

"Orangtuaku selalu pesan kalau beli barang harus dilakukan upacara Mappassili supaya terhindar dari masalah dan celaka". 
4. Sebagai bukti syukur pada Tuhan Yang Maha Kuasa

Seorang informan menyatakan hal sebagai berikut:

"Cara menyatakan syukur bisa dengan doa dan shalat atau ada juga yang melaksanakan nazar. Namun bagi saya, apa yang diajarkan oleh orang-orang tua seperti Mappassili merupakan cara kita mengucapkan syukur karena bisa membeli mobil, kalau kita bersyukur maka Insya Allah terhindar dari bahaya"

Pernyataan tersebut dapat dimaknai bahwa ritual Mappassili diyakini tidak bertentangan dengan ajaran agama, namun hanya merupakan implementasi berupa tindakan atau kegiatan untuk menunjukkan rasa syukur mereka. Ritual itu dapat bermacam-macam, namun terkait tolak bala maka tradisi Mappassili merupakan ritual yang cocok dilaksanakan.

5. Kebiasaan sejak dahulu.

Tradisi Mappassili sudah ada jauh sebelum masuknya Islam di Propinsi Sulawesi Selatan dengan Ibukota Makassar. Masyarakat sudah terbiasa melakukan hal tersebut. Awalnya tradisi Mappassili dilakukan untuk upacara pernikahan dengan memandikan sang calon pengantin dengan air kembang agar terhindar dari bencana atau kesialan dalam kehidupan kelak.

\section{$\underline{\text { Tingkat Kepuasan Pasca Pembelian Produk }}$}

Setelah dilakukan pengelompokan jawaban, maka diketahui bahwa masyarakat Kota Makassar yang bersuku Bugis-Makassar, akan merasakan kepuasan dalam penggunaan produk setelah dilakukannya tradisi Mappassili. 9 dari 20 informan menyatakan bahwa mereka merasakan sangat puas jika telah melakukan tradisi Mappassili segera setelah pembelian produk, dan hanya 5 informan yang menyatakan perasaan mereka biasa-biasa saja.

Sebagian besar informan menyatakan bahwa pelaksanaan tradisi tolak bala Mappassili sangat menentukan tingkat kepuasan mereka dalam penggunaan produk terutama untuk produk kendaraan. Konsumen Bugis-Makassar di Kota Makassar masih meyakini bahwa apabila tidak melakukan tradisi tersebut maka kemungkinan besar akan mendatangkan malapetaka, sehingga untuk menghindari hal tersebut maka mereka merasa wajib untuk melaksanakan upacara tradisi Mappassili.

Sementara itu, informan yang menganggap tradisi Mappassili sebagai sesuatu yang biasabiasa saja menyatakan bahwa mereka melakukan tradisi tersebut sekedar sebagai sebuah kebiasaan. Mereka berpendapat bahwa jika terjadi masalah dikemudian hari pada produk, bukan ditentukan oleh dilaksanakan atau tidak dilaksanakannya tradisi tersebut. Dengan demikian, dapat dikatakan bahwa budaya yang dianut oleh konsumen turut menentukan perilaku kepuasan pasca pembelian produk. Fenomena ini terlihat bahwa masyarakat lebih puas dalam penggunaan produk jika telah melakukan upacara tradisi Mappassili.

Berdasarkan paparan hasil penelitian, maka hasil penelitian ini mendukung penelitianpenelitian dan kajian mengenai keterkaitan budaya terhadap keputusan konsumen seperti yang dikemukakan oleh Kotler dan Keller (2012), Ahmed dan Ghingold (2007), Kacen dan Lee (2002), Jin dan Kim (2003), serta Karim (2016). Perkembangannya kemudian, ritual Mappassili juga dilakukan saat usai membeli produk tertentu seperti rumah dan kendaraan. Mappassili dilakukan pada rumah yang akan dihuni agar terhindar dari gangguan hal gaib, sementara pada kendaraan agar terhindar dari marabahaya (kecelakaan). Konsumen merasa wajib melakukan hal tersebut karena sudah terbiasa melihat dari orang tua mereka dan kemudian mengajarkankannya kepada anak-anak mereka.

\section{Kesimpulan}

Konsumen di Kota Makassar, khususnya suku Bugis-Makassar masih berpegang teguh pada tradisi yang diajarkan oleh nenek moyang mereka. Hal ini dapat dilihat pada perilaku pasca pembelian produk, yang mana bukan hanya kualitas yang menentukan kepuasan akan tetapi budaya juga memberi dampak terhadap kepuasan pasca pembelian. Konsumen lebih merasa terjamin 
keselamatannya dan kenyamanannya saat menggunakan produk jika telah melakukan tradisi Mappassili. Hal ini juga disebabkan oleh desakan orang tua atau keluarga yang mengkhawatirkan terjadinya malapetaka jika tidak dilakukan. Temuan lain menunjukkan bahwa konsumen melakukan tradisi ini sebagai cara untuk mengucap syukur kepada Tuhan Yang Maha Esa dan sebagai kebiasaan yang telah turun temurun diajarkan oleh leluhur mereka.

\section{Saran}

Penelitian ini merupakan penelitian kualitatif yang bertujuan mendapatkan makna dari perilaku yang ditampakkan oleh informan, sehingga belum memperlihatkan pengaruh secara kuantitatif antara kepuasan terkait budaya dengan perilaku pasca pembelian. Penelitian selanjutnya diharapkan dapat mengkaji pengaruh pelaksanaan tradisi budaya terhadap kepuasan pasca pembelian. Selain itu, dapat dilakukan kajian yang sejenis pada suku-suku lainnya yang ada di Indonesia, mengingat upacara tolak bala juga dilakukan oleh masyarakat di semua suku yang ada di Indonesia meski dengan bentuk yang berbeda, sehingga didapatkan hasil yang beragam dan informasi yang utuh mengenai keterkaitan budaya dengan kepuasan konsumen.

Implikasi manajerial pada penelitian ini adalah pemasar dalam melakukan pengenalan dan promosi produk hendaknya memperhatikan budaya yang dianut calon konsumen pada segmen pasar yang dipilih. Hal ini disebabkan perbedaan budaya akan memperlihatkan perbedaan perlakuan terhadap sebuah produk. Pemasar harus memahami bahwa meskipun masyarakat tinggal pada wilayah yang sama, namun bisa saja memiliki budaya atau adat istiadat yang berbeda terkait perilaku kepuasan terhadap sebuah produk pasca pembeliannya. Pemasar tidak hanya mendekati calon konsumen dengan menonjolkan kualitas produk, akan tetapi juga kepuasan pasca pembelian yang dikaitkan dengan budaya. Dengan demikian, pemasar dapat memposisikan produk di benak konsumen, yang dapat berdampak terhadap keinginan untuk melakukan pembelian ulang.

\section{Daftar Referensi}

Creswell, J.W. 2014. Research Design, 4th ed. V. Knight, ed., Sage Publication Ltd. Available at: https://www.researchgate.net/file.PostFileL oader.html?id...assetKey...

Giorgi, A. 1991. Phenomenology and Psychological Research, Duquesne University Press

Kamaruddin, A. R., and Kamaruddin, K. 2009. Malay culture and consumer decision-making styles: an investigation on religious and ethnic dimensions, Jurnal Kemanusiaan Bil.14 Malay

Karim, K. 2016. Mall shopping behavior of bugis consumer in Makassar, Indonesia I., Malang: Dream Litera.

Kotler, P. and Keller, K.L. 2012. Marketing Management, 14th ed. New Jersey: Prentice Hall.

Lin, W.-B., 2008. Factors Influencing Online and Post-purchase Behavior and Construction of Relevant Models. Journal of International Consumer Marketing, 20(64), pp.23-38.

Luchiyw, R., 2014. Berbagai Adat Tradisi Suku Bugis 1. pp.1-9.

Milles, M.B., Huberman, A.M., and Saldaña, J. 2014. Qualitative Data Analysis 3rd ed., Sage Publication Ltd.

Moleong, L. J. 2010. Metodologi Penelitian Kualitatif. Bandung: Remaja Rosdakarya.

Mosahab, R. 2010. Service Quality, Customer Satisfaction and Loyalty: A Test of Mediation. International Business, 3(4), pp.72-80.

Noble, D.F., Sander, J.K., and Obenshain, C.M., 1999. Cultural Influences in Decision Making. Evidence Based Research, Inc, p.11.

Pujangkoro, S. A., 2003. Perilaku Konsumen Setelah Pembelian, USU digital library.

Sugiyono, 2013. Metode Penelitian, Bandung: Alphabeta. Available at: http://www.ncbi.nlm.nih.gov/pubmed/1500 3161.

Swimberghe, Krist, Sharma, Dheeraj, Fluvvy, L. 2006. An exploratory investigation of the consumer religious commitment and its influence on store loyalty and consumer complaint intentions. Journal of Consumer Marketing, 26(5), pp.340-347. 